Article

\title{
Decomposition Analysis of the Mechanism Behind the Spatial and Temporal Patterns of Changes in Carbon Bio-Sequestration in China
}

\author{
Jinyan Zhan ${ }^{1, *}$, Haiming Yan ${ }^{1}$, Bin Chen ${ }^{1}$, Jiao Luo ${ }^{1}$ and Nana Shi ${ }^{2}$ \\ 1 State Key Laboratory of Water Environment Simulation, School of Environment, Beijing Normal \\ University, Beijing, 100875, China; E-Mails: yanhm.simlab@gmail.com (H.Y.); \\ chenb@bnu.edu.cn (B.C.); luoj_simlab@163.com (J.L.) \\ 2 Institute of Geographic Sciences and Natural Resources Research, Chinese Academy of Sciences, \\ Beijing 100101, China; E-Mail: shinn.dls@gmail.com \\ * Author to whom correspondence should be addressed; E-Mail: zhanjy@bnu.edu.cn; \\ Tel.: +86-10-59893226; Fax: +86-10-58807368.
}

Received: 28 December 2011; in revised form: 13 February 2012 / Accepted: 14 February 2012 / Published: 22 February 2012

\begin{abstract}
Great attention has been paid to carbon bio-sequestration due to increasing concerns over global warming. Understanding the relationship between carbon bio-sequestration and its influencing factors is of great significance for formulating appropriate management measures for global warming mitigation. Since change in carbon bio-sequestration is a complex process, it is difficult to take into account all of its influencing factors, while the panel data model may provide an effective way to measure their subtle effects. In this paper, decomposition analysis is applied to further analyze these influencing factors. The results indicate that climatic, demographic and geographical variables play important roles in explaining the spatial heterogeneity of carbon bio-sequestration in China, which is consistent with previous researches. Meanwhile, the irrigation rate is found to be the most critical factor influencing carbon bio-sequestration changes, followed by climatic and economic factors. These results may provide decision makers in China with important scientific reference information for formulating regional carbon bio-sequestration management policies, which are of great significance to alleviating and adapting to global warming.
\end{abstract}

Keywords: carbon bio-sequestration; decomposition analyses; panel data model; China 


\section{Introduction}

Increasing concern over climate change has brought great attention to carbon bio-sequestration [1,2]. Triggered by various factors, concentration of atmospheric carbon dioxide $\left(\mathrm{CO}_{2}\right)$ has increased greatly, which induces global warming and threatens the survival of human beings [3,4]. Plants in the terrestrial ecosystem can absorb $\mathrm{CO}_{2}$ from the atmosphere into their plant bodies and soil in the form of biomass. As an effective way to mitigate global warming, carbon bio-sequestration contributes greatly to sustainable economic development, environmental conservation and food security $[5,6]$. Since carbon bio-sequestration in the terrestrial ecosystem is influenced by various factors, awareness of its influencing mechanism is of great significance to formulating appropriate management policies for global warming mitigation at regional level [7].

It has been scientifically proven that various factors are responsible for spatial variability of carbon bio-sequestration [8-10]. Specifically, changes in climate, land use and soil attributes over the past few decades have raised serious concerns [8,9]. For example, researchers has found out that climate change affects local biological processes (i.e., photosynthesis, respiration and soil carbon decomposition) to some extent, which will interfere with global carbon cycle in the long run [10]. It has also been confirmed that spatial variation of carbon bio-sequestration was mainly induced by fluctuations in precipitation and solar radiation [11]. As an enormous organic carbon sink, soil demonstrates conspicuous spatial heterogeneity, which gives rise to carbon bio-sequestration diversity at regional level [12]. Human activities such as afforestation, ecosystem management and economic development influence carbon bio-sequestration simultaneously, among which land use change plays a key role [13]. Land use change alters the function and structure of terrestrial ecosystems and hence the carbon storage and flux in terrestrial ecosystems [10]. Recently, considerable efforts have been laid on the influence of climate and land use change. However, carbon bio-sequestration is a dynamic process incurred by a wide range of factors, and the key one may differ among regions. Therefore, more attention should be paid to all potential influencing factors and their spatial heterogeneities, which is the prerequisite for formulating corresponding management policies.

Increasing attention has also been paid to carbon bio-sequestration in China, the third largest country in the world. The climate has become warmer in China during the past few decades. The annual average temperature has increased by $0.5-0.8^{\circ} \mathrm{C}$, with significant heterogeneity among regions [14]. Simultaneously, rapid economic development as well as significant land use changes concurred on a large scale. Using NPP (Net Primary Productivity) as indicator of carbon bio-sequestration, this paper aims to explore the driving mechanisms behind carbon bio-sequestration changes in China based on panel data of 1988, 1995 and 2000 so as to assist in proposing various kinds of decision strategies for ecosystem management agents. The result can provide important scientific reference information for formulating regional carbon bio-sequestration management policies, which are of great significance to alleviating and adapting to global warming. 


\section{Data and Methodology}

\subsection{Methodology}

A panel data model was developed with an econometric approach to figure out specific functioning of diverse factors with spatial-temporal significances. In this panel data model, change in carbon biosequestration was defined as explained variable; potential factors, including the natural conditions and socioeconomic factors, were selected according to previous researches $[10,14]$ and expert knowledge and assigned as explanatory variables [see Equation (1)].

It is necessary to find a measurable indicator of carbon bio-sequestration, which is hard to measure directly. NPP is the net fixed carbon from atmosphere into plant per unit time, namely the sum of daily net growth or accumulating rate of plant dry matter [15,16]. NPP plays a significant role in the carbon biogeochemical cycle [17], and a considerable number of researchers have represented carbon bio-sequestration with NPP [18-20]. Therefore, NPP has been employed as a measurable indicator of carbon bio-sequestration in this study.

Using stepwise estimation, we explored effects of potential influencing factors on carbon bio-sequestration changes from 1988 to 2000 . We initially calculated the logarithm of all variables in the panel data model to eliminate influence of measurement error:

$$
\begin{aligned}
\ln (\text { npp })_{i t} & =\alpha_{i}+\beta_{1} \ln (\text { temp })_{i t}+\beta_{1} \ln (\text { rain })_{i t}+\beta_{1} \ln (\text { sun })_{i t}+\beta_{1} \ln (\text { ur })_{i t}+\beta_{1} \ln (\text { pop })_{i t} \\
& +\beta_{1} \ln (\text { a49pcT })_{i t}+\beta_{1} \ln (\text { irrif })_{i t}+\beta_{1} \ln \left(s g d p_{-} 2\right)_{i t}+\beta_{1} \ln \left(s g d p_{-} 3\right)_{i t}+\mu_{i t}
\end{aligned}
$$

where $i$ is observation unit; $t$ is time-series including 1988, 1995 and 2000; $\alpha_{i}$ and $\mu_{i t}$ are error terms.

The fixed effects model and random effects model were used to control the marginal effects due to potential co-relationship among variables. The fixed effects model allows each observation to have its own intercept by creating a set of dummy (either 0 or 1 ) variables as regressors. If individual effect is correlated with any regressors, the random effect estimator will be biased and inconsistent, whereas, the random effect estimator will be consistent if individual effects are independent from regressors. The fixed effect estimator eliminates those biased effects and keeps the consistent ones.

Decomposition analysis is a mathematical instrument to determine the contribution of changes in single driving forces (both decreases and increases) on changes in a dependent variable between two periods. The change in each driving force describes its impacts on the dependent variable's change while leaving all other independent variables unchanged. Therefore, decomposition analysis has been used to further explore driving factors of carbon bio-sequestration in this study, since it takes into account both magnitude of change and coefficients of influencing factors.

\subsection{Data Collection and Processing}

It is necessary to first gather and integrate detailed information of the case study area. A database was built, covering both explanatory and explained factors from 1988 to 2000. Explanatory factors were categorized into five groups in this study, i.e., climatic factors, land use factors, geophysical factors, transportation and location factors, and socio-economic factors (see Table 1). 
Table 1. Variables for decomposing the causality of carbon bio-sequestration change in China.

\begin{tabular}{|c|c|c|c|c|c|c|}
\hline Variables & Unit & Meaning & Average & Std & Minimum & Maximum \\
\hline NPP & $\mathrm{gC} / \mathrm{m}^{2} \cdot \mathrm{a}^{-1}$ & Net primary productivity & 9062.791 & 4863.321 & 0 & 23224.4 \\
\hline Temp & ${ }^{\circ} \mathrm{C}$ & Temperature & 11.699 & 5.813 & -8.105 & 24 \\
\hline Rain & $\mathrm{mm}$ & Precipitation & 873.625 & 481.878 & 11.786 & 2418.6 \\
\hline Sun & $\mathrm{h}$ & Sunshine hour & 2098.945 & 547.804 & 837.500 & 3487.896 \\
\hline $\mathrm{Ur}$ & $\%$ & Relative humidity & 67.832 & 10.402 & 32.806 & 85.692 \\
\hline Pop & $10^{4}$ person & Population & 50.205 & 49.105 & 0.504 & 1081.733 \\
\hline AgInvest & $10^{4}$ yuan & Agricultural investment & 7.212 & 37.367 & 0.00152 & 1386.769 \\
\hline Irri & $\%$ & Irrigation rate & 0.48 & 0.184 & 0.151 & 0.999 \\
\hline Gdp & $10^{4}$ yuan & Gross domestic product & 30.248 & 85.433 & 0.209 & 3648.774 \\
\hline Denhighf & $\mathrm{km}$ & Density of highway & 0.0306 & 0.0972 & 0 & 0.920 \\
\hline Sgdp_2 & $\%$ & $\begin{array}{l}\text { Share of the second } \\
\text { industry in total GDP }\end{array}$ & 0.344 & 0.152 & 0.0217 & 0.927 \\
\hline Sgdp_3 & $\%$ & $\begin{array}{l}\text { Share of the tertiary } \\
\text { industry in total GDP }\end{array}$ & 0.287 & 0.0957 & 0.0166 & 0.907 \\
\hline Splain & $\%$ & Share of plain area & 0.332 & 0.376 & 0 & 1 \\
\hline Dem & $\mathrm{m}$ & Altitude & 873.029 & 1113.1 & 0 & 5162 \\
\hline Slo & $\circ$ & Slope & 3.029 & 2.976 & 0 & 17.38 \\
\hline Soil_n & $\mathrm{mg} / \mathrm{kg}$ & Nitrogen content in soil & 0.173 & 0.166 & 0 & 2.38 \\
\hline
\end{tabular}

\subsubsection{Carbon Bio-Sequestration}

In this study, we used NPP as the explained indicator of changes in carbon bio-sequestration (Figure 1). Value of NPP was retrieved with GLO-PEM model [21-23], using the Pathfinder AVHRR Land (PAL) data at a resolution of $8 \mathrm{~km}$ and 10 days in 1988, 1995 and 2000 [24]. The incident Photo Active Radiation (PAR) and factors influencing its use efficiency were retrieved, and NPP was calculated with the following equation:

$$
N P P=\sum_{t=1}^{12}\left(P A R_{t} \times F P A R_{t} \times \varepsilon_{g}-R_{\alpha}\right)
$$

where $P A R_{t}$ is PAR in time $t ; F P A R_{t}$ is the fraction of incident PAR absorbed by vegetation canopy, calculated as a linear function of NDVI; $\varepsilon_{g}$ is use efficiency of $P A R$ absorbed by vegetation in terms of gross primary production; $R_{\alpha}$ is autotrophic respiration calculated as a function of standing above-ground biomass, air temperature and photosynthetic rate.

\subsubsection{Climatic Factors}

Climatic factors included temperature, annual precipitation, annual sunshine hours and relative humidity, all of which dominated spatial and temporal patterns of carbon bio-sequestration at regional scale. All of those climate data between 1988 and 2000 were derived from daily records of observation stations maintained by the China Meteorological Administration. Monthly mean data was employed to calculate the annual average values of temperature, precipitation, sunshine hours and relative humidity. 
Figure 1. Changes in NPP during 1988-1995 and 1995-2000 in China.
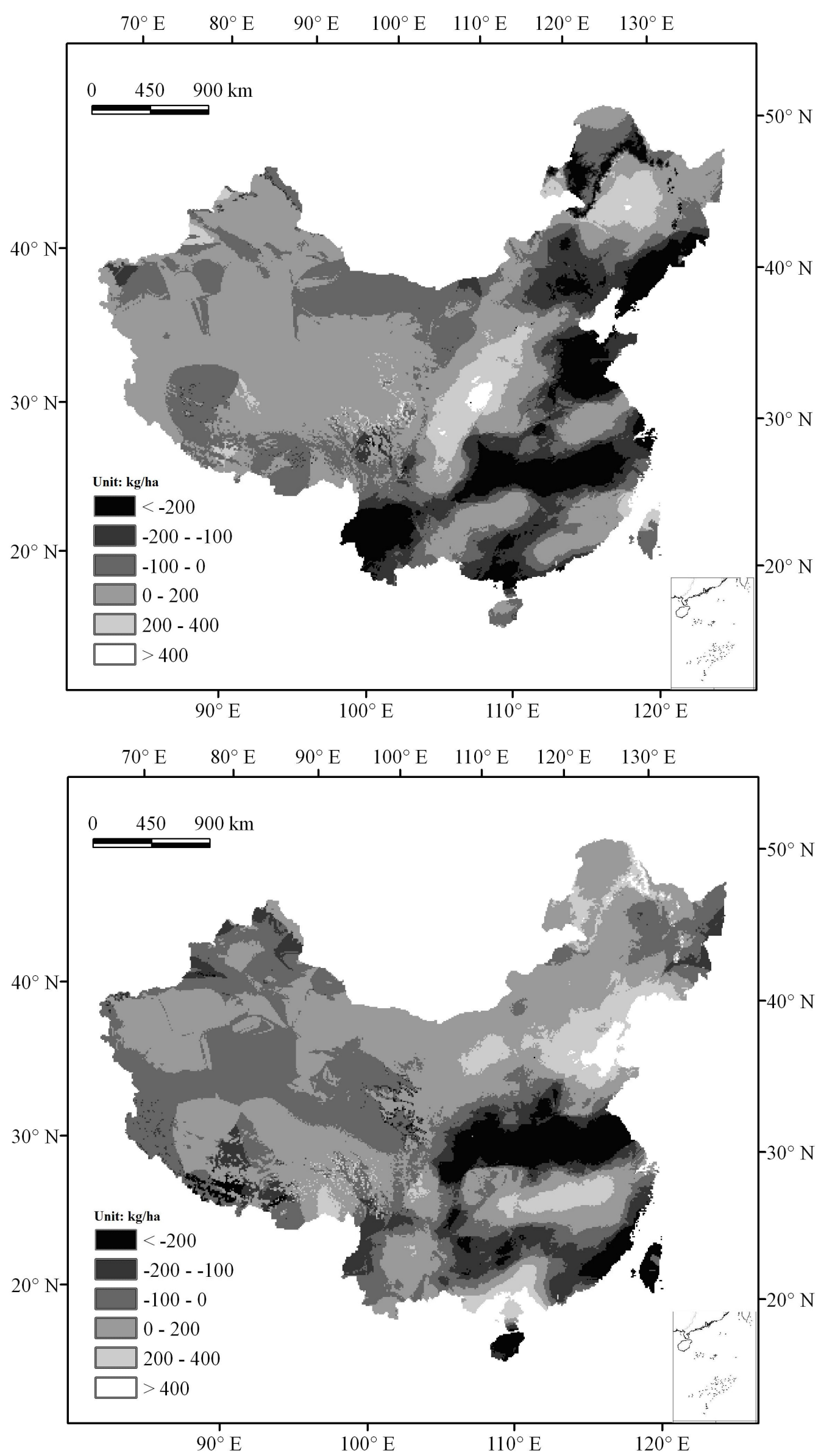
The original meteorological database was saved in form of text, and was interpolate into $1 \mathrm{~km} \times 1 \mathrm{~km}$ grid using gradient plus inverse distance squares method [25]. In addition, since temperature declines linearly with increasing elevation, the interpolated temperature data was adjusted to sea level according to altitude data which was calculated based on the Digital Elevation Model (DEM) dataset developed by Chinese Academy of Sciences.

\subsubsection{Land Use Factors}

Land use database used in this study was derived from Landsat TM/ETM images in 1988, 1995 and 2000 at $1 \mathrm{~km}$ spatial resolution, which was interpreted by Chinese Academy of Sciences (CAS) [26]. The interpretation accuracy is as high as $92.7 \%$ according to field survey and random sampling verifications. Six types of land use were employed in this study, i.e., cultivated land, forestry area, grassland, water area, built-up area and unused land [27]. The 1-km grid data covering the entirety of China was generated with the framework of the 1-km GRID dataset [28].

\subsubsection{Geophysical Factors}

Geophysical factors covered altitude, slope, share of plain area and soil properties. Slope, altitude and plain area proportion data were generated from DEM data at a scale of 1:250,000. All information of soil properties was from the second national soil survey and finally interpreted into $1 \mathrm{~km} \times 1 \mathrm{~km}$ grid pixel data using Kriging method.

\subsubsection{Transportation and Location Factors}

Distance data represented distance from any pixel to the nearest expressway or water area. Highway density value was calculated with road length divided by total land area within each county or city. These data was calculated using measuring tools based on road network, water area maps, which were derived from the topographic map of China at a scale of 1:250,000.

\subsubsection{Socio-Economic Factors}

Socio-economic factors included total population, GDP, GDP of the secondary industry, GDP of the tertiary industry, irrigation investment, and irrigation rate. Irrigation investment and irrigation rates data were collected by field investigations in the years of 1988, 1995 and 2000. All other socio-economic data were from China County/City Socio-Economic Statistical Yearbook, supplemented by provincial annual statistical yearbooks.

\section{Results}

\subsection{Results of the Fixed Effect Model}

The basic model in Equation (1) was firstly run with the fixed effects method, and effects of factors influencing carbon bio-sequestration are very clear (Table 2). The result indicated natural conditions played a fundamental role in change of bio-sequestration. For example, climatic conditions played a key role in promoting bio-sequestration. With value of carbon bio-sequestration in 1988 held constant, 
the importance of climatic factors (Temp, Rain, Sun, Ur) was demonstrated by their positive and highly significant coefficients when climatic factors were solely included in the model (Column 1 in Table 2).

Table 2. Results from the OLS model of carbon bio-sequestration change in China.

\begin{tabular}{|c|c|c|c|c|c|c|}
\hline & \multicolumn{6}{|c|}{$\ln (\mathbf{n p p})$} \\
\hline & (1) & (2) & (3) & (4) & (5) & (6) \\
\hline Lntemp & $\begin{array}{l}0.021 \\
(5.39) * * *\end{array}$ & $\begin{array}{l}0.029 \\
(7.19) * * *\end{array}$ & $\begin{array}{l}0.029 \\
(6.43) * * *\end{array}$ & $\begin{array}{l}0.028 \\
(6.18) * * *\end{array}$ & $\begin{array}{l}0.027 \\
(5.84) * * *\end{array}$ & $\begin{array}{l}0.040 \\
(7.79) * * *\end{array}$ \\
\hline Lnrain & $\begin{array}{l}0.028 \\
(5.98) * * *\end{array}$ & $\begin{array}{l}0.029 \\
(6.16) * * *\end{array}$ & $\begin{array}{l}0.054 \\
(9.51) * * *\end{array}$ & $\begin{array}{l}0.054 \\
(9.28) * * *\end{array}$ & $\begin{array}{l}0.050 \\
(8.54) * * *\end{array}$ & $\begin{array}{l}0.052 \\
(8.57) * * *\end{array}$ \\
\hline Lnsun & $\begin{array}{l}0.051 \\
(4.05) * * *\end{array}$ & $\begin{array}{l}0.069 \\
(5.40) * * *\end{array}$ & $\begin{array}{l}0.042 \\
(3.10) * * *\end{array}$ & $\begin{array}{l}0.035 \\
(2.52) * *\end{array}$ & $\begin{array}{l}0.049 \\
(3.39) * * *\end{array}$ & $\begin{array}{l}0.111 \\
(7.06) * * *\end{array}$ \\
\hline Ur & $\begin{array}{l}0.002 \\
(4.08) * * *\end{array}$ & $\begin{array}{l}0.002 \\
(5.22) * * *\end{array}$ & $\begin{array}{l}0.002 \\
(4.71) * * *\end{array}$ & $\begin{array}{l}0.002 \\
(4.66) * * *\end{array}$ & $\begin{array}{l}0.003 \\
(5.62) * * *\end{array}$ & $\begin{array}{l}0.004 \\
(7.01) * * *\end{array}$ \\
\hline lnnpp1988 & $\begin{array}{l}0.933 \\
(188.15) * * *\end{array}$ & $\begin{array}{l}0.933 \\
(186.94) * * *\end{array}$ & $\begin{array}{l}0.912 \\
(166.98) * * *\end{array}$ & $\begin{array}{l}0.909 \\
(163.75) * * *\end{array}$ & $\begin{array}{l}0.913 \\
(162.71) * * *\end{array}$ & $\begin{array}{l}0.910 \\
(159.10) * * *\end{array}$ \\
\hline Lnpop & & $\begin{array}{l}-0.018 \\
(7.34) * * *\end{array}$ & $\begin{array}{l}-0.017 \\
(6.39) * * *\end{array}$ & $\begin{array}{l}-0.028 \\
(6.39) * * *\end{array}$ & $\begin{array}{l}-0.018 \\
(3.46) * * *\end{array}$ & $\begin{array}{l}-0.017 \\
(3.40) * * *\end{array}$ \\
\hline lnAgInvest & & & $\begin{array}{l}0.005 \\
(5.33) * * *\end{array}$ & $\begin{array}{l}0.005 \\
(4.97) * * *\end{array}$ & $\begin{array}{l}0.005 \\
(5.13) * * *\end{array}$ & $\begin{array}{l}0.004 \\
(4.33) * * *\end{array}$ \\
\hline Irri & & & $\begin{array}{l}0.123 \\
(10.69) * * *\end{array}$ & $\begin{array}{l}0.118 \\
(9.34) * * *\end{array}$ & $\begin{array}{l}0.119 \\
(9.50) * * *\end{array}$ & $\begin{array}{l}0.146 \\
(11.47) * * *\end{array}$ \\
\hline Lngdp & & & & $\begin{array}{l}0.009 \\
(2.98) * * *\end{array}$ & $\begin{array}{l}-0.003 \\
(0.67)\end{array}$ & $\begin{array}{l}0.008 \\
(1.76) *\end{array}$ \\
\hline Lndenhighf & & & & $\begin{array}{l}-0.001 \\
(1.66) *\end{array}$ & $\begin{array}{l}-0.001 \\
(1.84) *\end{array}$ & $\begin{array}{l}-0.001 \\
(1.72) *\end{array}$ \\
\hline Sgdp_2 & & & & & $\begin{array}{l}0.066 \\
(3.58) * * *\end{array}$ & $\begin{array}{l}0.049 \\
(2.70) * * *\end{array}$ \\
\hline Sgdp_3 & & & & & $\begin{array}{l}0.090 \\
(3.99) * * *\end{array}$ & $\begin{array}{l}0.055 \\
(2.43) * *\end{array}$ \\
\hline Splain & & & & & & $\begin{array}{l}-0.017 \\
(1.81) *\end{array}$ \\
\hline Lndem & & & & & & $\begin{array}{l}0.012 \\
(5.84) * * *\end{array}$ \\
\hline Lnslo & & & & & & $\begin{array}{l}-0.002 \\
(1.08)\end{array}$ \\
\hline lnsoil_n & & & & & & $\begin{array}{l}0.013 \\
(3.11) * * *\end{array}$ \\
\hline Constant & $\begin{array}{l}-0.153 \\
(1.28)\end{array}$ & $\begin{array}{l}-0.287 \\
(2.38) * *\end{array}$ & $\begin{array}{l}-0.136 \\
(1.05)\end{array}$ & $\begin{array}{l}-0.041 \\
(0.30)\end{array}$ & $\begin{array}{l}-0.252 \\
(1.76) *\end{array}$ & $\begin{array}{l}-0.860 \\
(5.54) * * *\end{array}$ \\
\hline Observations & 4406 & 4372 & 3870 & 3845 & 3845 & 3845 \\
\hline R-squared & 0.96 & 0.96 & 0.96 & 0.96 & 0.96 & 0.96 \\
\hline
\end{tabular}

Note: $t$ statistics in parentheses; ${ }^{*}$ significant at $10 \% ; * *$ significant at $5 \% ; * * *$ significant at $1 \%$. 
The increase of these climatic factors can accelerate biological processes, promote plant growth and consequently increase bio-sequestration. For example, the coefficient of temperature was 0.021 , intuitively demonstrating that carbon bio-sequestration will increase by $0.21 \%$ if temperature increases by $10 \%$. Furthermore, with other explanatory variables incrementally added in the modified models i.e., Column (2) to (6) in Table 2, coefficients of climatic factors gradually changed, while remaining statistically significant (Column 6 in Table 2). Moreover, the highly adjusted R-squares in Columns (1) to (6) also illustrated that climatic factors were responsible for the major variation in carbon bio-sequestration. In addition, geophysical factors including terrain and soil play a fundamental role in influencing plant growth and distribution, favorable terrain and soil can significantly promote increase of bio-sequestration; The result indicated that altitude (dem) and nitrogen in soil (soil_n) were statistically significant $(p<0.01)$ when holding climatic factors constant and had positive effects on change of bio-sequestration.

Socioeconomic factors have very important impacts on bio-sequestration. The results indicated that population (pop), agricultural investment (AgInvest), irrigation rate (Irri), industrialization (sgdp_2) were all statistically significant $(p<0.01)$ when holding climatic factors constant. Population had very significantly negative effects on bio-sequestration; the coefficient of population was -0.017 , indicating that carbon bio-sequestration would decrease by $0.17 \%$ if population increased by $10 \%$. Population growth may intensify human disturbance on forests and grassland, for example, decrease forest area, forest fragmentation, which will decrease bio-sequestration. While agricultural investment and irritation rate can significantly promote plant growth in cultivated land and consequently increase bio-sequestration; the result indicated their coefficients were both positive and statistically significant $(p<0.01)$, and irritation rate had more important influence on bio-sequestration.

Socioeconomic development indirectly influences plant growth and distribution. The result indicated increase of share of the second industry in total GDP and share of the tertiary industry in total GDP led to increase of bio-sequestration; the coefficient of industrialization variable (sgdp_2) was positive and significantly distinguished from zero (Column 5 in Table 2) and influence of GDP of tertiary industry (sgdp_3) was positive at 5\% significance level. The development of the second industry and tertiary industry can absorb more population into urban area, and may reduce human disturbance on natural ecosystems and promote the recovery of plants; besides, economic development provides financial basis for increasing irrigation rate and agricultural investment.

All coefficients of explanatory variables were statistically significant when we used the OLS estimator. According to the result of the OLS estimator, it may be somewhat surprising that coefficient of share of the second industry in total GDP (sgdp2) was smaller than that of tertiary industry (sgdp3). On the whole, signs and significance of all of these variables suggested that variables in the model, including both economic variables and demographic variables, were useful in explaining changes in carbon bio-sequestration in China. Special attention should be paid to the difference between Column (6) and other columns in Table 2. Coefficients of most variables changed significantly when more variables were gradually added. Climatic, demographic and geographical variables played important roles in explaining changes in carbon bio-sequestration. In order to measure their impacts more precisely, it was necessary to control the effects of economic variables. 


\subsection{Results of the Random Effect Model}

The effects of influencing factors on bio-sequestration were further estimated with the random effect method. The results obtained with the fixed effects method distinguished significantly from that with the random effects method. The shortcoming of failing in controlling all random effects was very clear when comparing Table 2 to Table 3. It is prominent that coefficients of some variables changed significantly. On one hand, coefficients of population, agricultural investment (AgInvest), expansion of the second industry (sgdp_2) and the tertiary industry (sgdp_3) decreased sharply and finally became insignificant in the random effects model. On the other hand, coefficients of the rest variables, e.g., irrigation rate, GDP and temperature, precipitation are always significant in both models [Columns (1)-(6) in Table 2] with high values. In other words, the changes in carbon bio-sequestration are likely to be induced by rapid income growth process rather than by population growth or industrialization. These differences were significant when comparing the coefficients from above models. When using the OLS framework, a 10\% increase of GDP led to an increase of carbon bio-sequestration by $0.08 \%$; while the increase was $0.38 \%$ when using the panel data model and controlling all the time-varying effects.

Table 3. Results from the panel-data model of the changes in carbon bio-sequestration in China.

\begin{tabular}{|c|c|c|c|c|c|c|}
\hline & \multicolumn{6}{|c|}{ Ln(npp) } \\
\hline & (1) & (2) & (3) & (4) & (5) & (6) \\
\hline Lntemp & $\begin{array}{l}0.300 \\
(30.16) * * *\end{array}$ & $\begin{array}{l}0.272 \\
(25.96) * * *\end{array}$ & $\begin{array}{l}0.244 \\
(22.19) * * *\end{array}$ & $\begin{array}{l}0.270 \\
(22.55) * * *\end{array}$ & $\begin{array}{l}0.273 \\
(22.65) * * *\end{array}$ & $\begin{array}{l}0.276 \\
(22.50) * * *\end{array}$ \\
\hline Lnrain & $\begin{array}{l}0.051 \\
(4.60) * * *\end{array}$ & $\begin{array}{l}0.049 \\
(4.48) * * *\end{array}$ & $\begin{array}{l}0.083 \\
(7.62) * * *\end{array}$ & $\begin{array}{l}0.134 \\
(10.89) * * *\end{array}$ & $\begin{array}{l}0.135 \\
(10.96) * * *\end{array}$ & $\begin{array}{l}0.137 \\
(10.99) * * *\end{array}$ \\
\hline Lnsun & $\begin{array}{l}0.111 \\
(2.59) * * *\end{array}$ & $\begin{array}{l}0.065 \\
(1.51)\end{array}$ & $\begin{array}{l}0.031 \\
(0.74)\end{array}$ & $\begin{array}{l}0.057 \\
(1.30)\end{array}$ & $\begin{array}{l}0.060 \\
(1.35)\end{array}$ & $\begin{array}{l}0.072 \\
(1.54)\end{array}$ \\
\hline Ur & $\begin{array}{l}0.027 \\
(20.42) * * *\end{array}$ & $\begin{array}{l}0.025 \\
(18.64) * * *\end{array}$ & $\begin{array}{l}0.021 \\
(15.26) * * *\end{array}$ & $\begin{array}{l}0.021 \\
(14.40) * * *\end{array}$ & $\begin{array}{l}0.021 \\
(14.22) * * *\end{array}$ & $\begin{array}{l}0.021 \\
(14.22) * * *\end{array}$ \\
\hline Lnpop & & $\begin{array}{l}0.074 \\
(7.14) * * *\end{array}$ & $\begin{array}{l}-0.019 \\
(1.40)\end{array}$ & $\begin{array}{l}0.018 \\
(1.22)\end{array}$ & $\begin{array}{l}0.016 \\
(1.03)\end{array}$ & $\begin{array}{l}0.018 \\
(1.16)\end{array}$ \\
\hline Lngdp & & & $\begin{array}{l}0.083 \\
(12.48) * * *\end{array}$ & $\begin{array}{l}0.034 \\
(4.21) * * *\end{array}$ & $\begin{array}{l}0.036 \\
(3.72) * * *\end{array}$ & $\begin{array}{l}0.038 \\
(3.80) * * *\end{array}$ \\
\hline LnAgInvest & & & & $\begin{array}{l}0.001 \\
(0.22)\end{array}$ & $\begin{array}{l}0.001 \\
(0.18)\end{array}$ & $\begin{array}{l}0.000 \\
(0.13)\end{array}$ \\
\hline Irri & & & & $\begin{array}{l}0.357 \\
(10.49) * * *\end{array}$ & $\begin{array}{l}0.351 \\
(10.25) * * *\end{array}$ & $\begin{array}{l}0.355 \\
(10.32) * * *\end{array}$ \\
\hline Sgdp_2 & & & & & $\begin{array}{l}-0.041 \\
(0.98)\end{array}$ & $\begin{array}{l}-0.043 \\
(1.03)\end{array}$ \\
\hline Sgdp_3 & & & & & $\begin{array}{l}0.049 \\
(1.10)\end{array}$ & $\begin{array}{l}0.045 \\
(1.01)\end{array}$ \\
\hline Constant & $\begin{array}{l}5.239 \\
(13.09) * * *\end{array}$ & $\begin{array}{l}5.542 \\
(13.90) * * *\end{array}$ & $\begin{array}{l}6.046 \\
(15.30) * * *\end{array}$ & $\begin{array}{l}5.277 \\
(12.73) * * *\end{array}$ & $\begin{array}{l}5.260 \\
(12.49) * * *\end{array}$ & $\begin{array}{l}5.107 \\
(11.24) * * *\end{array}$ \\
\hline Observations & 4406 & 4372 & 4302 & 3845 & 3845 & 3845 \\
\hline R-squared & 0.0408 & 0.0483 & 0.1126 & 0.1304 & 0.1323 & 0.1323 \\
\hline
\end{tabular}

Note: $t$ statistics in parentheses; $*$ significant at $10 \%$; * significant at $5 \%$; *** significant at $1 \%$. 
Such differences may bias decision making as China experiences rapid economic growth. In addition, the results of both the fixed effect model and the random effect model only measures the marginal effects of these influencing factors on the bio-sequestration, it is necessary to further measure total contribution of these influencing factors to change of bio-sequestration.

\subsection{Decomposition Analysis}

The results obtained with the panel data model (Table 3) were assumed to be accurate and realistic, and decomposition analysis was carried out to further analyze effects of the explanatory factors. Using methods different from those employed in previous studies, it was found that climatic factors played an important role in influencing carbon bio-sequestration, which was consistent with the conclusions of previous research. Using the methods proposed by previous studies [19,29], the importance of variables according to their coefficients was sequenced as irrigation rate, temperature, rainfall, GDP and relative humidity (Ur) on a general downtrend. The results of the decomposition analysis (Table 4) confirmed the findings of the panel data model. Climatic factors including temperature, rainfall and relative humidity positively influenced the changes in carbon bio-sequestration; while their roles were not dominant, explaining only $7.19 \%$ of carbon bio-sequestration change as a whole. GDP was the second important influencing factor, which indicated that carbon bio-sequestration would increase by $1.998 \%$ if GDP increased by $52.58 \%$.

Table 4 Decomposition analysis of the changes in carbon bio-sequestration in China, 1988 to 2000 .

(1)

(2)

(3)

(4)

\begin{tabular}{lcccc}
\multicolumn{1}{c}{ Variables } & $\begin{array}{c}\text { Estimated } \\
\text { parameter }\end{array}$ & $\begin{array}{c}\text { Percentage changes } \\
\text { in variables }\end{array}$ & $\begin{array}{c}\text { Impact on carbon } \\
\text { bio-sequestration (\%) }\end{array}$ & $\begin{array}{c}\text { Contribution } \\
\text { (\%) }\end{array}$ \\
\hline Based on Column 5 in Table 3 & & & & \\
Temperature & 0.276 & 1.01 & 0.280 & 4.083 \\
Rainfall & 0.137 & 1.21 & 0.166 & 2.418 \\
Sunshine & 0.072 & -3.37 & -0.243 & -3.546 \\
Relative humanity & 0.021 & 2.26 & 0.047 & 0.693 \\
GDP & 0.038 & 52.58 & 1.998 & 29.175 \\
AgInvest & 0.000 & 2.89 & 0.000 & 0.000 \\
Irrigation rate & 0.355 & 13.17 & 4.677 & 68.289 \\
Sgdp_2 & -0.043 & 5.69 & -0.245 & -3.572 \\
Sgdp_3 & 0.045 & 15.24 & 0.686 & 10.014 \\
Residual & & & -0.517 & -7.55 \\
NPP change & & 6.85 & & 100 \\
\hline
\end{tabular}

Note: For ratios of GDP of the second or tertiary industry, they are measured as changes in the ratios. The decomposition analysis was conducted with following steps. Firstly, percentage change of each variable was calculated (Column 2); Secondly, Column (2) was multiplied by parameters estimated with the fixed effects model (Column 1) to obtain impact of each variable on carbon bio-sequestration (Column 3); Finally, impact of each variable (Column 3) was divided by percentage change of carbon bio-sequestration during this period to obtain contribution of each variable (Column 4). 
In comparison, the influence of irrigation rate was completely dominant. In fact, it explained $68.29 \%$ of the changes in carbon bio-sequestration (Table 4), which meant that carbon bio-sequestration would increase by $4.677 \%$ if irrigation rate increased by $13.17 \%$. However, carbon bio-sequestration only increased by $6.85 \%$ in fact, indicating that there were some other (unmeasured) factors that decreased carbon bio-sequestration. Such differences may bias decision making as China experiences rapid economic growth. In addition, the results of both the fixed effect model and the random effect model only measures the marginal effects of these influencing factors on the bio-sequestration, it is necessary to further measure total contribution of these influencing factors to change of bio-sequestration.

\section{Discussion and Conclusions}

Influencing mechanism of carbon bio-sequestration was explored with the econometric model, the result of which was fairly clear and generally consistent with previous findings [30-33]. However, it is still necessary to include spatial data of carbon bio-sequestration and time-varying factors such as economic or demographic factors in the future research. The results may change greatly if time-varying data are available and a panel data model is used.

Since carbon bio-sequestration change is a complex process, it is difficult to take into account all of its influencing factors. It would be an effective way to measure the subtle effects using panel data model with either the fixed effects method or the random effects method. Based on both models, the results of this study revealed the importance of socio-economic factors and climatic factors in influencing dynamics of carbon bio-sequestration. On the one hand, population, agricultural investment, temperature, precipitation, relative humidity and development of the third industry all affected carbon bio-sequestration; however, their roles were not that important. On the other hand, irrigation rates played a dominant role according to the results in this study.

Although policy was not explicitly considered in this study, the results of decomposition analysis suggested that there was something else responsible for decreasing in carbon bio-sequestration. Influence of these anonymous factors was embodied in the residual, which made carbon bio-sequestration decreased by $7.55 \%$. It is impossible to interpret the meaning of residual precisely, while it is still possible to speculate that human activities may have played a role in decreasing carbon bio-sequestration. Deforestation such as the unnecessary cutting of trees, clearing forests for crop land or ranches for raising cattle and over-grazing in the 1980s and early 1990s may have contributed to the decrease in carbon bio-sequestration. Although that decrease was not stopped, the new environmental policies (e.g., Green for Grain) after 1998 may have helped to alleviate this decreasing trend, for example, the total afforestation area has reached 20.5 million $\mathrm{hm}^{2}$ by 2007 , among which 9.1 million $\mathrm{hm}^{2}$ was converted from farmland.

\section{Acknowledgements}

This research was supported by the National Basic Research Program of China (973 Program) (No. 2010CB950904). Data supports from projects of the National Natural Science Foundation of China (No. 40801231; No. 70873118; No. 41071343) and the National Key Technologies R\&D Program of Ministry of Science and Technology of the People's Republic of China (No. 2008BAK50B05; 
No. 2008BAK50B06) are also appreciated. We thank three anonymous reviewers for their helpful advices and comments, especially the second anonymous reviewer's comments about the secondary emission of $\mathrm{CO}_{2}$ in agriculture, which helps improve our manuscript greatly.

\section{References}

1. IPCC. Climate Change 2001: The Scientific Basis; Cambridge University Press: Cambridge, UK, 2001.

2. Hughen, K.; Lehman, S.; Southon, J.; Overpeck, J.; Marchal, O.; Herring, C.; Turnbull, J. ${ }^{14} \mathrm{C}$ activity and global carbon cycle changes over the past 50,000 years. Science 2004, 303, 202-207.

3. IPCC. Land Use, Land-Use Change, and Forestry: A Special Report of the Intergovernmental Panel on Climate Change; Cambridge University Press: Cambridge, UK, 2000.

4. IGBP Terrestrial Carbon Working Group. The terrestrial carbon cycle: Implication for the Kyotol protocol. Science 1998, 280, 1393-1394.

5. Hardisty, P.E.; Sivapalan, M.; Brooks, P. The environmental and economic sustainability of carbon capture and storage. Int. J. Environ. Res. Public Health 2011, 8, 1460-1477.

6. Butterworth, W. The Technology of waste, biofuels and global warming in viable closed loop, sustainable operations. Energies 2009, 2, 1192-1200.

7. Lynch, D.; Macrae, R.; Martin, R. The carbon and global warming potential impacts of organic farming: Does it have a significant role in an energy constrained world? Sustainability 2011, 3, $322-362$.

8. Cramer, W.; Kicklighter, D.; Bondeau, A.; Moore, B.; Churkina, C.; Nemry, B.; Ruimy, A.; Schloss, A.L. Comparing global models of terrestrial net primary productivity (NPP): Overview and key results. Glob. Change Biol. 1999, 5, 1-15.

9. Ahl, D.E.; Gower, S.T.; Mackay, D.S.; Burrowsa, S.N.; Normanc, J.M.; Diakd, G.R. The effects of aggregated land cover data on estimating NPP in northern Wisconsin. Remote Sens. Environ. 2005, 97, 1-14.

10. Gao, Z.; Liu, J.; Cao, M.; Li, K.; Tao, B. Impacts of land-use and climate changes on ecosystem productivity and carbon cycle in the cropping-grazing transitional zone in China. Sci. China Ser. D 2005, 48, 1479-1491.

11. Potter, C.; Klooster, S.; Tan, P.; Steinbachc, M.; Kumarc, V.; Genoveseb, V. Variability in terrestrial carbon sinks over two decades: Part 2-Eurasia. Glob. Planet. Change 2005, 49, $177-186$.

12. Liski, J.; Perruchoud, D.; Karjalainen, T. Increasing carbon stocks in the forest soils of western Europe. For. Ecol. Manag. 2002, 169, 159-175.

13. Houghton, R.; Hackler, J.; Lawrence, K. The US carbon budget: Contributions from land-use change. Science. 1999, 285, 574-578.

14. Sha, W.; Shao, X.; Huang, M. Climate warming and its impact on natural regional boundaries in China in the 1980s. Sci. China Ser. D 2002, 45, 1099-1113.

15. Goudriaan, J. Global carbon cycle and carbon bio-sequestration. In Carbon Sequestration in the Biosphere-Processes and Prospects; Springer Verlag, Heidelberg: Berlin, Germany, 1995; pp. 3-18. 
16. Mohamed, M.; Babiker, I.; Chen, Z.; Ikedaa, K.; Ohtaa, K.; Katoa, K. The role of climate variability in the inter-annual variation of terrestrial net primary production (NPP). Sci. Total Environ. 2004, 332, 123-137.

17. Cox, P.M.; Betts, R.A.; Jones, C.D.; Spall, S.A.; Totterdell, I.J. Acceleration of global warming due to carbon-cycle feedbacks in a coupled climate model. Nature 2000, 408, 184-187.

18. Liu, J.; Chen, J.; Cihlar, J.; Park, W.M. A process-based boreal ecosystem productivity simulator using remote sensing inputs. Remote Sens. Environ. 1997, 62, 158-175.

19. Gao, Z.; Liu, J.; Cao, M. Impacts of land use and climate change on regional net primary productivity. J. Geogr. Sci. 2004, 3, 349-358.

20. Wang, J.; Chen, J.; Ju, W.; Li, M. IA-SDSS: A GIS-based land use decision support system with consideration of carbon bio-sequestration. Environ. Model. Softw. 2010, 25, 539-553.

21. Kawase, R.; Matsuoka, Y.; Fujino, J. Decomposition analysis of CO2 emission in long-term climate stabilization scenarios. Energy Policy 2006, 34, 2113-2122.

22. Prince, S.D.; Goward, S.N. Global primary production: A remote sensing approach. J. Biogeogr. 1995, 815-835.

23. Yang, J.; Prince, S.D. A theoretical assessment of the relation between woody canopy cover and red reflectance. Remote Sens. Environ. 1997, 59, 428-439.

24. Cao, M.; Prince, S.D.; Li, K.; Tao, B.; Small, J.; Shao, X. Response of terrestrial carbon uptake to climate interannual variability in China. Glob. Change Biol. 2003, 9, 536-546.

25. Mardikis, M.; Kalivas, D.; Kollias, V. Comparison of interpolation methods for the prediction of reference evapotranspiration-An application in Greece. Water Resour. Manag. 2005, 19, 251-278.

26. Deng, X.; Huang, J.; Rozelle, S.; Uchida, E. Growth, population and industrialization and urban land expansion of China. J. Urban Econ. 2008, 63, 96-115.

27. Deng, X.; Huang, J.; Rozelle, S.; Uchida, E. Economic growth and the expansion of urban land in China. Urban Stud. 2010, 47, 813-843.

28. Deng, X.; Jiang, Q.; Su, H.; Wu, F. Trace forest conversions in Northeast China with a 1-km area percentage data model. J. Appl. Remote Sens. 2010, 4, 1-13.

29. Liu, X.H.; Wang, J.F.; Liu, M.L.; Meng, B. Spatial heterogeneity of the driving forces of cropland change in China. Sci. China Ser. D 2005, 48, 2231-2240.

30. Zhao, X.; Chen, B.; Yang, Z.F. National water footprint in an input-output framework-A case study of China 2002. Ecol. Model. 2009, 220, 245-253.

31. Chen, G.Q.; Chen, B. Extended exergy analysis of the Chinese society. Energy 2009, 34, $1127-1144$.

32. Zhou, J.B.; Jiang, M.M.; Chen, B.; Chen, G.Q. Emergy evaluations for constructed wetland and conventional wastewater treatments. Commun. Nonlinear Sci. Numer. Simul. 2009, 14, 1781-1789.

33. Chen, B.; Chen, G.Q.; Hao, F.H.; Yang, Z.F. Emergy-based energy and material metabolism of the Yellow River Basin. Commun. Nonlinear Sci. Numer. Simul. 2009, 14, 923-934.

(C) 2012 by the authors; licensee MDPI, Basel, Switzerland. This article is an open access article distributed under the terms and conditions of the Creative Commons Attribution license (http://creativecommons.org/licenses/by/3.0/). 